Dejan DONEV

UDK: 27-36Св. Наум Охридски:27-145.55-42

Review article

\title{
A THOUGHT ON THE ETHICS OF SAINT NAUM'S MIRACULOUSNESS AND ON THE NATIONAL SPIRIT
}

\begin{abstract}
Starting from the fact that it is not enough to just get rid of evil, but that the essence is to get away from the evil and get the evil away, and you can only do that when you start doing good, seemly to man as a temple of God - it becomes clear why and how an ethics of practical action, as is the case with St. Clement from Ohrid, grows into an ethics of spiritual shaping of the space and the people where they live. That St. Clement manages this, there is a proof in the case of St. Naum, so it should come as no surprise that in addition to being proclaimed a saint, he is more often called a "miraculous".

One can become a "miraculous" when a certain group declares certain "healings" as a miracle of God, or when, understanding the ethics of his teachers Cyril and Methodius, but above all Clement's, they become the starting point for creating a space in which man will come up to what the man is doing - a spiritual space in which he will find himself opening up to the Spirit. At the same time, without violating the identity of God, monastic or canonical, and opening space for building churches the walls of which will give space for anticipatory commentary on the world, but also space for those who will enter them by looking at the frescoes, the icons, listening to the word of God, come to themselves as a temple of God, but universally ethically constructed - is the result that confirms this ethics of miraculousness, the ethics of the people's spirit. Such an ethical qualification of Naum's life result is also the subject of analysis of this text.
\end{abstract}

Keywords: MIRACULOUSNESS, MIRACLE WORKER, MIRACULOUS, SAINT, ETHICS

\section{Introduction}

If St. Clement of Ohrid was remembered in the collective folk memory through his enlightenment activity, through the teaching of the people not only in writing and reading, but also in other practical things, the character and work of St. Naum remained engraved in that memory as a teacher, educator, but most of all as a miraculous who has the power to heal both during life and after death from various diseases and people of different religions. But from this aspect of analysis, perhaps more importantly, St. Naum was remembered for protecting the monastery, not only as a place to literate people and to convey what was known, but mostly to reward those who came to the monastery with good intentions. 
Namely, starting from the fact that it is not enough just to get rid of evil, but that the essence is to get away from evil and get the evil away, and you can do that only when you start to act well, good to man as God's temple - it becomes clearly why and how an ethics of practical action, as is the case with St. Clement, grows into an ethics of spiritual shaping of the space and people where one lives. That St. Clement does this is proof of the thesis of St. Naum Miraculous from Ohrid - spirituality in the full gist of the word in its all-encompassing meaning can only be achieved if conditions are first created which man, both as a body and as a being, they will bring him to the awareness of his duty to God. And this can only be done not only by the material conditions, but also the spiritual space, to allow each of us in our own way and in proportion to our needs and opportunities, to find ourselves in God's temples or on the painted walls.

\section{Bio / Bible note}

Despite the scarce information about the life of St. Naum, and even more so due to the fact that his life was in many ways overshadowed by the life of St. Clement, however, according to available sources (both Slavic biographies, ${ }^{1}$ Greek biography, ${ }^{2}$ Pannonian legends and Spacious Clement's biography) it is possible to make at least a partial reconstruction of the life cord of this educator, clergyman and missionary, one of the founders of Slavic and Macedonian literacy.

According to the legends, "the most characteristic of which is the tradition of St. Clement of Ohrid" (Антиќ, 1982: 25-26), which is based on the life of Theophylact of Ohrid, St. Naum was born in the first half of the IX century, grew up in Mysia, "brought up by his noble (parents), he considered all nobility and wealth as a chaff..." (Миловска, 1996: 87). As one of the Pentecostals and closest disciples who worked with the Slavic equal apostles Cyril and Methodius, St. Naum from his youth faithfully followed the teachers in Moravia, Pannonia, where for many years he preached the God's will to people in their native language. He trained them in literacy, disseminated the liturgical books translated from the ancient Greek language into Slavic by the Apostolic Bro-

\footnotetext{
${ }^{1}$ The first, the oldest, originated in the first half of the $10^{\text {th }}$ century, and is known from the $15^{\text {th }}$ century inscription - "December, the twenty-third day, remembrance of our venerable and pious father Naum, the great miraculous, in Livanie Devolsko, near Ohrid." The second Slavic Naum's biography is newer - "The month of December (day) the twenty-third, a memory of our Venerable Father Naum". It is known from a transcript made in the $16^{\text {th }}$ century. According to Добрила Миловска, Македонски житија IX XVIII век, Скопје: Табернакул, 1996, p. 11. More details, Михајло Георгиевски, Македонски светци, Скопје: Култура, 1997, р. 67.

2 There is an opinion that the second Slavic Naum's biography is a translation from Greek or a compilation from Greek sources. According to Йорданъ Ивановъ, Български старини изъ Македония, София: Бъдгарско книжовно дружество, 1931, р.240.
} 
thers, and in 868 the confirmation came from Rome, when Pope Adrian II (867872) acknowledged the deed of worship of the Slavic teachers, consecrated the Slavic books and blessed the liturgy in the Slavic language, and St. Naum, among others, was ordained a presbyter. (Миловска, 1996: 88)

After the death of the Slavic teacher Methodius in 885, a fierce battle broke out in Moravia between the students of the Thessalonian brothers Cyril and Methodius and the German priests. The preachers were thrown into darkness, chained, subjected to torture, sold as slaves in Venice, and some brutally expelled across the border. St. Naum is also among the expelled holy preachers, who, moved by God's providence, reached the Danube where they were divided into groups. Some of them went to Mysia, others to Dalmatia and Dacia, "multiplying the word of God everywhere a hundredfold" (Миловска, 1996: 89). St. Naum, together with Saints Clement and Angelarius, travelled to Bulgaria, where the Bulgarian Tsar Boris received them with joy, because he needed such students. He wanted to expand his influence in the western parts, more precisely in Macedonia (История македонского народа, 1986: 21). He sent Saint Clement as a teacher to Macedonia, in Kutmichevica (somewhere between Ohrid, Devol and Glavenica), opening the Ohrid Literary Centre, while St. Naum remained in the capital Pliska, to organize a Slavic educational and literary centre. Although not in the capital Pliska, where the Byzantine archbishop of Bulgaria resided, but in the nearby Slavic town of Preslav, St. Naum opened the door to the Preslav Literary Centre, ${ }^{3}$ teaching and preaching in a monastery built in honour of St. Panteleimon, near Preslav (886-893). ${ }^{4}$

In 893, at a church-people's assembly, when his "brother" Clement was ordained a Slavic bishop at Velika, Bulgarian King Simeon sent Naum to his teaching post in Kutmichevica. Thus, "Naum and Clement came to the lands of Illyria and Lychnidos" (Миловска, 1996: 89). Here St. Naum began the enlightenment work, which they performed for seven years together with St. Clement (Миневски, 2015: 24), i.e. in Macedonia, at the Ohrid Literary School, rising as the second chief representative in the Ohrid Literary Centre.

It is known that he was engaged in literary activity, although unfortunately today not a single work signed with his name is known. Perhaps out of modesty or some other reason, he did not put his name anywhere, although in the words of Constantine Bregalnichki it is said that Naum gave him the impetus to write The Glorious Gospel. (Поленаковиќ, 2007: 344) However, what left a deep mark is the indefatigable work (with St. Clement) on the translation of the Holy Scriptures and other Greek-Slavic church books, which is why they were also called "the new Moses and Aaron." ${ }^{\text {- }}$

\footnotetext{
${ }^{3}$ While Angelarius, meanwhile, died.

${ }^{4}$ That is why he is considered one of the founders of the Preslav Literary School

${ }^{5}$ In the Greek synagogue, St. Clement and St. Naum were called "the new Moses and Aaron," and this miracle is spread about them: "heretics in Germany chained them and
} 
While in Ohrid St. Clement performed the sacred/episcopal works, St. Naum, as a wise teacher, miraculous ${ }^{6}$ and prayer leader, around whom many monks gathered (Миневски, 2015: 24) - built a monastery in honour of the Holy Archangels (today's St. Naum), on the southern shore of Lake Ohrid, which has become a source of piety ${ }^{7}$ and refuge for the poor. He stayed in the monastery he founded, which is popularly known as St. Naum's Monastery, for ten years, completing his 80-year journey and resting in peace on December 23, 910. There, even now, his holy relics rest, healing ${ }^{8}$ - with the power of Christ's grace - spiritual weaknesses and diseases (Митревски, 1983: 139), healing both during life and after death, healing from various diseases and people of different religions, ${ }^{9}$ that is all who sincerely and faithfully address him regardless of religion or nationality.

\section{The ethics of miraculousness}

Speaking of St. Naum the Miraculous, his work and ethics, we must first go back and recall St. Clement's ethics, which in principle can be defined as the ethics of the philosophy of education, as a way to reach those parts of our be-

throwned in the prison. But, by the will of God, the prison trebled, the chains had fallen out of their hands, and the door of the prison was opened, for them to go out freely."

${ }^{6} \mathrm{He}$ is also known as a miraculous, because he is said to have performed many miracles, some of which are depicted on frescoes in his monastery as "depicting a bear dragging its plow instead of the ox it ate." Other scenes from the life and miracles of St. Naum, painted in the second zone of Naum's Tombstone, also impress: "Stiffening of the monk who tried to steal St. Naum's body from his grave", "Treating the Nervous" on a horse which the dawn found before the doors of the monastery church "and" The cheerful one leaves a hollow in the stone ". In more detail, Цветан Грозданов, Свети Наум Охридски, МАНУ \& Матица Македонска, Скопје, 2015, and especially Стојан Ристески, Иегенди и преданија за свети Наум, Скопје: Институт за фолклор „Марко Цепенков", 1990, where 120 legends have been published.

${ }^{7}$ According to the first biography of St. Naum, the monastery was built in 900, according to the second in 905. This monastery dates back to the time of St. Naum with a rich fund of books, and later over the centuries it became a real foodstuff for Slavic books and manuscripts. Thus, this monastery, as well as the monastery of St. Clement can be included among the first Macedonian monasteries that had rich monastic libraries.

${ }^{8}$ The monastery was most affirmed as a healing place for the sick of many ailments, especially mental illness. The belief in the healing power of the holy relics of the saint contributed to this. There are a number of legends that tell about the healing of the mentally ill by the saint, that is that there was a mental hospital in the monastery for a long time. Стојан Ристески, Аегенди и преданија за свети Наум.

${ }^{9}$ That members of other faiths respected the saint and the monastery is discussed in a number of legends where it is said: "this sanctuary is called "Sari Saltik Baba" which translated from Turkish means yellow-bearded father. According to a legend, once when they came to the tomb of St. Naum, several Turks asked one of the most educated to explain the characters in the frescoes. When he explained to them, "This is St. Naum," they shouted, "And he is our father." 
ing, our existence, our consciousness, but also the parts of what in the cortex for which we do not always have a completely rational, scientific or exact explanation. In other words, it is through his concrete action that St. Clement, who has devoted most of his life to the study of the human body and the ways in which it is maintained in a state in which the body free from its weaknesses will be devoted to creation, enables the disciples and the followers at least a little bit to continue what he started - he created for his successors not only concrete results, but also instilled in them certain ways of thinking about man not only as a gift from God, but above all as something for which it has to think, so to come to God. In fact, it is a matter of establishing ethics that starts from the fact that God cannot exist, nor can He be reached, much less be His temple, if man does not first open himself for himself, before God, for God's sake.10

Understood in this way, applied and with proven results, St. Clement's ethics shows that spirituality in the full gist of the word, in its all-encompassing meaning, can only be achieved if conditions are created that first of man, both as a body and as a being, will bring him to the awareness of his duty to God. But not only to God to fulfil his purpose for us, but conditions that will bring him to the awareness of the duty to God to be human to man. And this can only be done not only by the material conditions, but also by the spiritual space, to allow each of us in our own way and proportionately to our needs and opportunities, to be found in God's temples or on the painted walls, such as painted in the churches of the city of Ohrid where St. Naum mostly created space through concrete action. ${ }^{11}$

However, this is not the only reason why St. Naum became a miraculous and a saint, much less explaining why he was declared as such. Namely, he could become a saint by starting or enabling the construction of a huge number of churches, bringing a large number of fresco painters and icon painters, who with their works, giving soul to the interior thereof, gave soul to the human interior. Thus, in any case, if not before God, then before mankind, he deserved the name of a saint, that is, he fulfilled not only his human - ethical obligation - to give his own to others, but also by not violating the ruling canons, he satisfied them and the conditions of the ecclesiastical authorities according to which one becomes a saint as the church requires, in order to be able to continue to perform his function in conditions in which he was more of a controller than a creator or liberator. ${ }^{12}$

${ }^{10}$ That is, the deification of man primarily has an ethical dimension, and not just an eschatological dimension - To be a Christian means to be ethical!

${ }_{11}$ Namely, St. Naum was remembered, among other things, for the protection of the monastery, after rewarding those who came to the monastery with good intentions and punishing those who went with the intention of doing some damage, polluting the building or insulting the saint.

${ }^{12}$ For a deeper insight into the current situation, it is advisable to look at Блаже Ристовски, Портрети и процеси од македонската литературна и нациионална историја 1, Скопје, Култура, 1989, р. 25-46. 
There is no doubt that this is the case, just as there is no doubt that the former does not make him a miraculous, so this question still remains open. Namely, a miraculous can be made in two ways. Most often, an authorized group of newsletters declares certain "healings" or "events" to be God's miracle. The second is when the ethics of his teachers Cyril and Methodius, but above all Clement, becomes the basis for creating a space in which man will come to what man does - a spiritual space in which he will find himself, opening himself to the Spirit - as in the case of St. Naum. (Темков, 1998: 80-97)

Such a space can be opened in several ways. But what Naum has certainly proven to be "miraculous" is the fact that by becoming one of the founders and leading people of the so-called Ohrid Literary School, better known as the "First Slavic University", aware of the fact that the written word at that time was not only a privilege of a certain class and a way for that same class to rule the people, but also by circumventing the knowledge that the world is valued, accepts or he refuses depending on what we see in him - among other things he founded the monastery today known as St. Naum. But to establish and build a monastery and thus become the first founder of a monastery in these areas, is not surprising in itself because it is beyond any doubt that such shrines are being built ex-nihilo as the world of God. The wonder is that, and that is what makes it essentially "miraculous" - it has made a connection, a synthesis between the rooted word of God and the painted word of God to the extent of man, as it is in the time we are in, but no less and for what and those who come. More importantly, the painters of those frescoes and icons, precisely because they worked under the auspices of a man who realized deep down that only by giving inner freedom to the idea, even if formally packaged, can we speak not only of the time in which they originated (frescoes and icons) (Грозданов, 2015: 215).

Namely, it is important that they have enabled the time they inherited and the people who evaluated or condemned them, regardless of their point of view, but in the end to know that there are values that do not depend on time or material conditions, but according to space that opens up as part of human life as a creature of God: not according to God's will not to feel alone, but as a creature that only by giving space to others in itself, opens space for itself in others, and thus open a space for a path to God.

It was in this way that he realized the role of the ethics of belief and action, St. Naum, rising from the ethics of St. Clement to another spiritual level opening space for self-discovery through the word and image of what is meant to be a God's temple - opens the way for those who come, on the "shoulders" of the former to reach/rise to the point where they will further open the way to others. This shows and proves the ethics of the miraculousness of St. Naum of Ohrid. True, this is exactly what makes this ethics miraculousness and him - a miraculous.

It is this grounded behaviour that has been proven to be ethical, leading to what, like nuanced words runs through the end of the text, are "miraculous", "miraculousness", "miraculus". Namely, "miracle workers" are people who per- 
formed miracles, and "miraculous" refers to those who did not perform a miracle, but caused a miracle that was directly or indirectly an example to him or his actions enabled others to discover and realize such a talent or such an ability. What has been said before introduces us to what makes him a "miraculous." Namely, if we understand it as "miraculous-miracle-provoking", that is a facilitator through their actions and science for others to discover in themselves the part that will allow them to do a miracle, that is first to return to themselves and discover themselves as human beings in which the temple of God becomes the same only when space is opened for others in them. At the same time, the miraculous does this because he has allowed others to discover themselves, to return to themselves as human beings, and thus, through their behaviour towards others, to show the treatment of human beings.

Thus, St. Naum works wonders in the circumstances in which he acts. Having in mind not only the political circumstances, but above all the economic circumstances in which he works, and especially knowing the theological/ canonical pressures to which he was exposed by Constantinople, and which was still influenced by the division before and after the Nicaean assemblies, his way to develop literacy, art, non-profitability, he opened a spiritual space in which a nation, recognizing truly real ethical values, will discover itself as an autochthonous and autonomous creature. This is the result of his ethics, which is still seen today after so many centuries, regardless of the current politicization of philosophy and philosophical politics. In particular, such an ethical view of its practical action has led to the awareness of an environment independent of daily events that can still remain human, ethically grounded and aware, regardless of various propaganda for possible reproduction, i.e. has shown how one can remain consistent with the thesis that no heritage, neither cultural nor biological, can be created without taking into account the capacity and possibilities of the space where it takes place!

The latter is not intended to enter into the daily political philosophizing or politicization of philosophy, but above all to point to the fact that people like St. Clement and St. Naum have become what they are - saints, not because they have been satisfied with the conditions of the "competition" for beatification. They have done so in the heritage of both the people and the culture precisely because, regardless of the politically challenged theological/canonical explanations, above all, they have shown by their practical activity that they start from man to enable him not only to return to himself for oneself, but for others. They did this to enable him, among other things, not only to live in harmony with God's word, but also to live free from the need to mediate between him and God, the canon, and the interpretation, which were not infrequently the main reasons for divisions, as it was in 1054.

\section{Instead of a conclusion...}

Mentioning the imposition and interpretation of the way the vision will continue is not because it seeks to enter into some controversy with the ruling 
theological or canonical interpretations of the functions of human existence on earth. Namely, speaking of St. Naum as miraculous, precisely because he gave many people space by painting frescoes to introduce man as a measure of understanding of God's inclination - he managed to open a space from which everyone had a benefit, and more importantly, from which space can all be freed from the fear of coming into conflict with the interpretation of God, to come to themselves and thus be recommended to Him.

Simply put, it is precisely this ethically motivated action and opening of space for others that St. Naum manages to indirectly create a consciousness within a community that has grown over time to self-awareness as an entity. Regardless of whether we follow the canonical instructions or not, we will still be able to maintain and continue if two things are understood from what has been presented, from what has been offered for insight, from what has been described and written as ways of interpreting God's words:

1. YES, we are God's creatures!; YES, we are here to continue some of the inclinations and enable it in its realization;

2. But above all, we are here because we have learned, consciously or unconsciously, to exist not according to the interpreted measure of God, but according to the perceived measure of the nature of things which tells us that we will be in harmony with God and with ourselves and with our proposed ethics, and mostly in mutual agreement and understanding, if we are able to continue the genus and thus do not endanger the survival of the species.

Such an attitude, in essence, means that the ethics of miraculousness of St. Naum of Ohrid can be spoken not only of the ethics of a faith, but also of the enlightenment of the future people and a future nation, but above all as for ethics that allows to understand that regardless of the name of the community, remains the man who belongs to humanity only if its existence and continuation does not endanger it. Although this claim may be less unusual, a clear parallel between the philosophy and ethics of St. Naum and what is later called the "Renaissance of Philosophy" would easily reveal a community in which, regardless of the function of the words signed by the canon, or the images in the name of the canon, however, there is the fact that both in those words and in those images man is recognized as the ultimate goal of the created. That is, it should be noted that, without disturbing the identity, neither God, nor monastic, nor canonical, and opening a space in which by building churches the walls of which will give space to anti-capitalist commentary and ethical orientation to the world, but also space to those who will enter them to see the icons, the frescoes, listening to the word of God, to come to themselves as a temple of God, but universally ethically built - its ethics is confirmed by the result as the ethics of miraculousness, and concrete evidence can be seen in the created cult of his person who radiated a wider space not only in the Ohrid region, but in Prespa, even to Korcha, where the monastery had its properties, and the cult of St. Naum had spread to Hungary and Romania where there were immigrants from these regions. 


\section{References:}

Антиќ, Стојчевска, Вера (1982). Климент и Наум Охридски во народната традиција. Скопје: Наша книга.

БАТАЛДЕН, К. Стивен (1997). Преиспитуваюе на традицијата. Скопје: Култура.

ВРАЖИНОвСКИ, Танас (1999). Народна традиција, религија и култура. Скопје: Матица македонска.

ГЕОРГИЕВСКИ, Михајло (1997). Македонски светции. Скопје: Култура.

ГРОЗдАНОВ, Цветан (2015). Свети Наум Охридски. Скопје: МАНУ \& Матица македонска.

ЗИЗИУлАС, Д. Јован (1998). Од маска до личност. Струмица: Манастир Света Богородица Елеуса.

ИвАнОвъ, Йорданъ (1931). Български старини изъ Македония. София: Българско книжовно дружество.

ИСТОРИЯ МАКЕДОНСКОГО НАРОДА. Скопье: Македонская академия наук и искусств, 1986.

МиловскА, Добрила (1996). Македонски житија IX - XVIII век. Скопје: Табернакул.

МИНЕвСКИ, Блаже (2015). „Чудата и благодатите на свети Наум биле побројни од ввездите на небото“.Дневник, година XIX, број 5806, петок, 3 јули 2015.

МитРевСКИ, Трајан (1983). Православна христијанска апологетика - Религијата и нејзиното оправдуване (основно богословие). Скопје: Православен богословски факултет „Свети Климент Охридски“

ПОЛЕНАКОВИќ, Харалампие (2007). Избрани дела 1 - Во мугрите на словенската писменост. Скопје: Култура.

РИСтЕВСКИ, Блаже (1989). Портрети и процеси од македонската литературна и нациинална историја 1. Скопје: Култура.

РистескИ, Стојан (1990). Аегенди и преданија за свети Наум. Скопје: Институт за фолклор „Марко Цепенков“.

SREMAC, Srđan \& Sergej Beuk (2013). Svet i sveto. Beograd: Otačnik.

ТЕмков, Кирия (1998). Етика. Скопје: Епоха. 